\title{
ANALYSIS OF STRATEGIC MANAGEMENT for ECOTOURISM DEVELOPMENT TOWARD COMMUNITY INVOLVEMENT AND NATURAL CONSERVATION at TM GUNUNG HALIMUN SALAK
}

\author{
Kurniawan Gilang Widagdyo \\ Universitas Sahid Jakarta
}

\begin{abstract}
Analysis of Strategic Management for Ecotourism Development Toward Community Involvement and Natural Conservation At TM Gunung Halimun Salak. This study was conducted in order to analyze ecotourism development within Taman Nasional Gunung Halimun Salak (TNGHS) area and determine association among its elements which is ecotourism activities, community involvement, and natural conservation. To convey comprehensive and factual result, theoretical considerations appear as basis for this study as well as qualitative and quantitative analysis. Some theories tend to be guidance that will be confront with qualitative data that was obtain from interview with several expertise and community's representative and compare with questionnaire distribution to determine how significant association occur between those three variables. The statistical analysis explains that ecotourism deliver positive impact toward local community and natural conservation.
\end{abstract}

Keywords: ecotourism, community involvement, natural conservation, correlation.

\begin{abstract}
Abstrak. Analisis Manajemen Strategik Terhadap Pengembangan Ekoturis Melalui Pemberdayaan Komunitas dan Konservasi Alam di TM Gunung Halimun Salak. Kajian ini dilakukan untuk menganalisis pengembangan ekoturis di Taman Nasional Gunung Halimun Salak dan menentukan hubungan antar elemen dimana kegiatan ekoturis, pemberdayaan komunitas, dan konservasi alam. Untuk mendapatkan suatu hasil yang komprehensif dan factual, pertimbangan teoritis dipergunakan sebagai dasar dalam studi ini dengan menggunakan analisis kualitatif dan kuantitatif. Beberapa teori dipergunakan sebagai pedoman yang akan dikonfrontasikan dengan data kualitatif, dimana data ini didapat dari wawancara terhadap beberapa ahli dan perwakilan komunitas serta membandingkan dengan kuesioner yang telah disebarkan. Analisis statistik yang didapat menjelaskan bahwa ekoturis memberikan dampak yang positif terhadap komunitas local dan konservasi alam.
\end{abstract}

Kata Kunci: ekoturis, pemberdayaan komunitas, konservasi alam, korelasi. 


\section{INTRODUCTION}

Indonesia therefore has great potential for development of ecotourism. However, the threat to biodiversity is also high with some apparent threats such as illegal logging, hunting, and other forms of destructive utilization of natural resources as well as tourism activities. Hence, a sustainable form of nature utilization, for instance ecotourism, is one of the alternative options in making the most of nature potential and at the same time conserving it. Furthermore, tourism development in Indonesia nowadays has been change from traditional development approach into brand new perspective of tourism that used to increase indigenous welfare. These local people are one of driving force that determine succeeded of tourism attraction where their participation are very crucial and play big role in order to develop tourism in particular destination.

Based on that fact, the opportunity to develop ecotourism as a strategy to build Sustainable Tourism is quite huge. It can be realized that ecotourism is a comprehensive tool to conserve biodiversity and to involve local communities and organization in a participatory way to derive maximum benefits in a sustainable way. Something to believe that ecotourism has a potential to improve the quality of the environment, cultural values, local community prosperity and quality of human relation in general. For instance is what has been done at Taman Nasional Gunung Halimun Salak (TNGHS) that applies ecotourism as form of solution for natural conservation and community empowerment.

This research assess and evaluates the potential of ecotourism as an alternative form of community's economic development and protection for natural biodiversity within the area that is significantly impacted by more traditional forms of mass tourism. It contributes to a larger literature on ecotourism as a form of sustainable development by applying ecotourism precepts rather than the conventional application of tourism in practical level. It also explores theoretical components of ecotourism by exploring a situation in which it may or may not be viable, depending on contextual and cultural factors. In keeping with the themes of ecotourism, the research evaluates the impact of 
tourism within natural biodiversity at TNGHS and highlights the degree of local people's involvement toward tourism activities as well as emphasize in degree of tourism involvement in term natural protection for its sustainable future.

Finally, the goals of this research are the evaluation and determination whether ecotourism appropriate to be applied as suitable form of solution for natural conservation and improvement in term of economic for local community within area of TNGHS (particularly at Citalahab village).

Regarding research aim, the question that might appropriate to rise in order to identified possibilities of ecotourism as alternative solution for natural conservation and community empowerment is: "Does ecotourism activities within TNGHS could improve local community's economic development and natural biodiversity conservation in compliance?"

Clearly, the aim of Taman Nasional Gunung Halimun Salak is consider as preservation park for biodiversity that are still remain till today, however its unique beautiful scenery and biodiversity has been attract many people to come and visit it. Therefore, mass tourism considers as threatens which conducted regardless balance of ecosystem within TNGHS thus, it is currently at stage where it is worthwhile to explore possibilities of ecotourism at TNGHS. The World Wildlife Foundation (WWF) and The International Ecotourism Society (TIES) which are both prominent leaders in the study and implementation of ecotourism worldwide propose basic preconditions to successful ecotourism (WWF, 2001), which are: first, a local community who aware of potential opportunities, risks, and changes involved with ecotourism. Second, a local community with a level of interest in ecotourism. Third, existing or potential structures either model or policy that appropriate to merge between; tourism, effective community's degree of involvement, and environmental protection into one sustainable tourism development program. Fourth, an initial market assessment suggesting representation of effective potential demand. Fifth, the initial of ecotourism form conducted in order to support nature and biodiversity conservation, not on the contrary. Sixth, organization that has intention and willing to support the implementation of ecotourism. Seven, 
landscape or flora/fauna with inherent attractiveness and appeal as the object of ecotourism.

The focus of this research is on the first four preconditions and a number of additional related questions which posses the following primary questions. First, how does ecotourism development within TNGHS ares? Second, does ecotourism could directly improve local community's economic development and natural-biodiversity protection? Third, what are ecotourism impacts through communities and biodiversity within the park?

By addressing these questions, this research contributes to the ecotourism literature by applying ecotourism precepts for sustainable, community-based tourism, and supporting natural conservation at TNGP area. A social construction view was taken regarding the creation of knowledge, which argues that realities are made of multiple mental constructions produced through social interactions and experiences. As Denzin and Lincoln (1998) note, realities are not more or less true in an absolute sense, but simply more or less informed, so that a person's constructed reality changes as they become more informed or sophisticated. Every truth is multi-faceted and a product of social construction-therefore the interview data was construed as partial representations of reality.

In order to overcome some of the problems encountered in describing tourism, the model was developed to highlight important participants and forces that shape the tourism industry (Cook et al., 2006). This model explains that tourism is something that interdependent with other factor that influenced it. This will notice its open nature and how each of the segments is related with others. Individual tourist may deal directly with any of these tourism service suppliers (Cook et al., 2006)

Community development practitioners are involved in organizing meetings and conducting searches within a community to identify problems, identify assets, locate resources, analyze local power structures, assess human needs, and investigate other concerns that comprise the community's character (case study). These practitioners, sometimes called social activists, use social resources to get the economic and political leverage that a community uses to 
meet their needs. Often, the social resources within the community are found to be adequate to meet these needs if individuals work collectively through techniques like cooperation and volunteerism. A form of community development that links academic resources to community problems in a reciprocally beneficial manner is Community-Based Participatory Research (CBPR), a form of research that equitably involves academic, practice, and community partners in all phases of research. It is important to note that there is a distinction between community-based participation research and community-placed research. The former gives the community an active role in the actual research planning and development which engages a community fully in the process of problem definition/issue selection, research design, conducting research, and interpreting the results (McGranaghan, 2007).

Ecotourism as one of community-based tourism form representing this particular notion quite well enough, ecotourism play important role as measurement for degree of involvement between local communities toward tourism development in their particular area. In term of strategic management, community involvement emphasizes in personification of community development concept. Wheelen and Hunger (2008) said Strategic Management as set of managerial decision and actions that determines the long-run performance which includes environmental scanning, strategy formulation, strategy implementation, and evaluation and control. In this situation community involvement stands to propose several strategic approaches regarding improvement of local community by persuade them to be involved in such tourism development in their area.

Furthermore degree of participation from local people could determine by notice how far local people get involved in the implementation of ecotourism. Community participation could be divided into several stage of involvement. Community Economic Development is often involved in a process of building social enterprises. Sometimes called the third sector, a community enterprise is a partnership between government agencies, small to medium enterprises, large national or transnational corporations and the not-for-profit 
sector, and aims for social, economic and/or environmental outcomes that none of these agencies could achieve for and by themselves.

\section{METHODS}

This research conducted in the area of Taman Nasional Gunung Halimun Salak (TNGHS) which is specifically in Citalahab village and its surrounding area, West Java Indonesia starting from August 2010 until November 2010. This research apply two kind of data sources which are primary and secondary data where the primary collected from questionnaire distribution toward local community also direct interview with persons to be concerned with this research. Moreover, direct observation (field study) also was conducted in order to enrich data and gain more information related with this research. Secondary data obtain from various articles, books, journal, and many other literatures study that concerned with this research. Additional sources such as internet, library, and other comprehensive written documentation also consider as secondary data that carrying out to completion of this research.

As mentioned by Supranto (1997) descriptive studies clarify the characteristics of situation or condition within an area, infrastructure, and particular circumstances. Descriptive researches mean to construct description regarding social or natural phenomenon systematically, factually, and accurately. Furthermore, this kind or research is used to answer particular hypothesis regarding particular event or circumstances that appear (Wardiyanta, 2006). Furthermore, descriptive-qualitative aproaches are used to explain the relationship of result from direct observation and interview with those components that directly involved within ecotourism activities in TNGHS.

Qualitative approach is considered as appropriate analysis instrument for this research because of its unique characteristic that fulfills necessity for qualitative approach. This research starting from the data and brings the result in final conclusion that appear from interpretation of those data, as Bungin (Isti'anah, 2001) was mentioned qualitative research initially begin from data and as a final point bring the result in one final conclusion. Bungin assumed that this kind of research tries to interpret or clarify the research findings in reality as discourse in order to give details concerning with factual condition. In 
addition, Hidayat (Dwiyanto, 2002) explained study field conducted in order to obtain all data related with scientific form. Researcher collecting the data by observation, deep interview, discussion with associated sources, and directly involve in evaluation or assessment. The stressed of qualitative approach is to construct and clarified the community involvement and conservation issues compare with theories, in order to construct that idea and bring it into grounded this research elaborate in-depth interview result and direct observation as the basis.

Moreover, the research follows the process of theory-based research (Dooley in Leksakundilok, 2004), which focus more on 'theory-then-research' rather than 'research-then-theory'. By conducting "in-depth interviewing" the research pays attention to the qualitative processes that seek in-depth understanding of the issues and attempts to describe the phenomenon without testing for causal pattern.

The participants were asked to complete a short semi-structured questionnaire containing open-ended question, the open-ended questions allowed participants to describe their ideas about nature-based tourism in an unstructured manner, resulting in a diversity of responses.

The used of quantitative approach is due to validate and support data and result that was conduct qualitatively. All the three values would be obtained from questionnaire that will be distributed into local community (Citalahab people) and visitor whithin surrounding area. The result convert into Guttman scale and analyze with Product Moment Pearson correlation, on the other hand qualitative answer will be acquired from personal in-depth interview and secondary data from Balai Taman Nasional Gunung Halimun Salak to support the quantitative ones.

Question raised divided into two forms, first is closed questionnaire form that asked to local people comprise of: first, demographic and identity question. Second, perception and their awareness regarding ecotourism. Third, frequency and degree of involvement within ecotourism implementation which comprise of several questions regarding economic benefit from ecotourism. Fourth, ecotourism and its impact in extent of natural conservation and 
biodiversity protection. Meanwhile, open ended question that will be asked to local administrator and other elements who involved within ecotourism development consist of: first, management of ecotourism development. Second, perception toward community involvement within ecotourism activities. Third, perception toward management of natural conservation within ecotourism destination.

\section{DISCUSSION}

As like most Natural Park in Indonesia, many local people live within TNGHS area for many years, away from TNGHS stated as Natural Park. At least there are more than 250.000 peoples live inside the park (Hartono et al, 2007), where most of this people are Sundanese which separated into several kasepuhan (community) and non Kasepuhan.

TNGHS area comprises of 314 villages and 26 subdistricts where 9 subdistricts located at Bogor regency, 8 subdistricts at Sukabumi regency, and the last of 9 subdistric lay in Lebak regency with total population approximately 606,375 peoples in 2005-2006 survey. Although most indigenous consider as Muslim, the old-belief (Sunda wiwitan) still be a part of their daily life mostly for elderly. It can be shown from their daily activities, interaction among community and nature, agricultural system, and house architecture. They believe nature provide everything they need for live, therefore balancing of life and harmonious among nature and human kind are something that need to maintain, otherwise nature will be ruin and human kind will bear the consequences.

Generally, as describe in table below most of local people who lived within TNGHS area work either in agricultural or horticultural sector. Spirit of mutual assistance and persistence among local community that combined with traditional agriculture knowledge are the key success that lead them as an excellent farmer which sustained well till present, local people utilized surrounding forest around their village in many ways such as swiddencultivation, rice-growing field, garden, mixed-garden, and mixed-forest. However, this traditional practice could lead into natural degradation and 
deforestation which might cause lost of natural ecosystem (Supriyanto et al, 2007).

Educational level of most people who lived with TNGHS area appertain as low educated especially in west part. Even though each village has own elementary school, yet number of junior high school are fewer which is only four schools whereas there is no senior high school within area of TNGHS consequently most people tend to feel reluctant to continue the study into higher level (Nugraheni, 2002), this educational level clearly stated in table 5 below. However, since area of mount Halimun and Salak consider as National Park, Kasepuhan community must be adaptable with current situation where they cannot easily utilize and exert the forest within their area since there are some regulations that arrange the function of forest and its surrounding area for the purpose of natural and biodiversity conservation.

There is something to consider that TNGHS have abundant tourism attractions where those attractions if well planned and organized could bring benefit toward local community and natural conservation. However, in order to overcome and prevent the impact of tourism toward natural conservation and biodiversity protection while also obtain benefit from tourism activities the notion of ecotourism appear and consider as solution for that matter. Moreover, several attractions that might appear as potential tourism destination are waterfall such as Cimantaja waterfall and Cipamulan waterfall, Piit waterfall, Walet waterfall, and Cikudapeah waterfall Citangkolo waterfall, Ciberang waterfall, Ciarnisah waterfall. Some waterfalls located in area of Salak mountain such as: Cangkuang waterfall (Cidahu), Pilung waterfall (Girijaya), Cibadak waterfall (Cijeruk), Citiis waterfall (Ciapus), Nangka waterfall (Taman Sari), Ciputri waterfall (Tenjolaya), Cihurang waterfall, Cigamea waterfall, Ngupet waterfall, and Seribu waterfall (Pamijahan), while the last is Cibereum waterfall (Jayanegara).

On the other hand, another attraction are Mountain peak, mountainous surface and adventurous terrain of TNGHS, ratu crater, Camping ground, Historical and sacred sites, Research station, Loop trail, Citalahab guest house and home stay, Canopy trail, Hot water spring, Tea plantation, Rafting, 
Traditional ceremony such as Seren taun, held once a year between June until December this unique traditional ceremony means to illustrate the feeling of grateful to God as every single livelihood, fortune and blessing they get. Usually celebrate in several kasepuhan like in Ciptagelar, Ciptamulya, Cicacurub, Cisitu, Citorek, and Urug.

The result of those interview explained in this section and then combined with direct observation as well as other literature study in order to minimize ambiguity and eliminate personal perception, since every opinion have various interpretation depend on its personal background characteristics, there will be no judgment regarding wrights or wrong in any extent. Beyond all, these elements were hardly tried and give their best effort to develop ecotourism within TNGHS area in sustainable direction.

There are two main general objective why ecotourism establish in the area of TNGHS, the first objective is for internal reasons where ecotourism eager to be such way due to reduce dependency of local people toward nature and ecosystem in order to fulfill their needs while in the other hand ecotourism also to be expected appear as motivation to boosted local community's awareness toward natural conservation. Meanwhile, second objective intended ecotourism as one of the way to promote TNGHS area as an area with richness in term of biodiversity and ecosystem, therefore information service of TNGHS need to be improved so that the park's existence and importance will be well recognized by people of Jakarta, Bogor, and other cities in surrounding area. Furthermore, ecotourism development process has been started since 1994/1995 in three section of TNGHS area which are north part (Leuwijamang), east part (Citalahab), and south part (Pangguyangan). Within those area guest house was built in order to provide accommodation for tourist and other visitor who came visiting. Those guest houses was built in cooperation with consortium-that was mentioned previously-where the management and operational activities of this guest house was charged to local community who joined in a local community's self-supporting group (Kelompok Swasadaya Masyarakat). 
Furthermore, relationship among KSM member and non active member are mutually exclusive, non active resident always support any kind of ecotourism activities such as by providing additional home stay when it will be needed and also their willingness to be tour guide. Moreover, this people also participate in order to provide some food and beverage for visitor who spend some nights in Citalahab village, they used to cook some local food while also offer catering service just like what visitor request.

In the direction of ecotourism implementation, these local people also conducting partnership with other parties such as local administration (Balai TNGHS) and Yayasan Ekowisata Halimun (YEH). These mutual partnerships bring advantages to local people where they can learn new thing regarding ecotourism development particularly at Citalahab village and its surrounding area, concerning this matter both parties maintain its fine relationship by obeying standard regulation that was agreed together.

Local community's involvement in ecotourism development starting with forming of local community's self-supporting group (KSM) which results from annual meeting that was held among local people in ones village. This meeting held in order to register number of local resident who able to become a member of this group and also to determine person in charge for the group (head of the group). Meanwhile, other parties like NGO and Balai TNGHS that joined in a consortium facilitating this meeting by giving suggestion toward working agenda. However, some people says since beginning they did not asking to be involved concerning ecotourism development planning phase, nevertheless since main resolution has decided they were asked to be involve in every meeting, in fact some of suggestion tend to be delivered in realization.

Development process of guest house formerly conducted by local people in the direction and designed by architect from consortium; the concept of this building is to build simple guest house which is quite comfortable and appropriate enough with health requirement. This building also should convey particular atmosphere so that visitor could feel be one with nature, and for this reason the guest house was built by most of natural material that obtain from surrounding such as bamboo handcraft for its wall, wooden shape for its floor, 
and also furniture made by wood, even some guest house has rumbia leaf as their rooftop.

Local people also prepared by several skills regarding ecotourism competency such as training for tour guiding, cooking, and food preparation. The trainer which came from consortium elements such as YEH, Balai TNGHS and even INDECON giving some training and information regarding skill that needed for ecotourism activities, local people were trained to be generous and friendly host in term of serving the guest who came to Citalahab. Furthermore, this people also trained to be entrepreneur by teach them how to creates and develop traditional crafting also how to manage gust house and home stay in general.

Nevertheless, since the project of ecotourism consortium was over, number of visitor were decrease, this is occur regarding to lack of promotion and publication effort in mass media. Basically all member of KSM are eager to be involved in this ecotourism development program since there are some benefit they could obtained besides additional income from tourism sector, local people who become member of KSM were trained to be more independent and creative. These member also skilled with new knowledge concerning with tourism, organizational behavior, and communication skill to interact with other people, however since number of tourist were decrease and there is a tendency that income from tourism sector tend to be more uncertainty those people seems prefer back to works in plantation sector, this situation is makes sense because from this sector those local people could receive regular salary from payment in every month as their job compensation whereas in tourism sector there is uncertainty situation where their income are depend on number of tourist coming and number of tourist expenditure in their area.

Especially within Citalahab area, at least there are 30 peoples from more or less 63 of total population who actively joined in KSM Warga Saluyu, these members are half of population where the rest of Citalahab resident are working in plantation sector and some others going abroad from the village meant for working in nearest major cities like Jakarta, Bogor, and Sukabumi. 
However, all local people especially within Citalahab village consider ecotourism as profitable sector besides agriculture and animal husbandry that could obtain additional income for them, besides that they also perceived ecotourism as something interesting and exciting where they could meet and interact with other people while also improved their skill and knowledge especially improvement in English language where they never had before.

Within this stage, local people in Citalahab village are urging to be host with nice attitude and warmth behavior, and to accomplish these people prepared with several tourism skills such as tour guiding and attitude training. Local people also taught to be friendlier and be open with foreigner, this is really important to show their courtesy into visitor so that visitor will feel more pleasant and clannish.

Since the propose notion of ecotourism development is to increase local community's welfare, local people were urge to be involved in every ecotourism activities, for example most of male in Citalahab village are trained to be able to provide tour guiding service while also become educator for visitor, guider should be able to explain various type of animal and plant and its characteristic that they meet inside the jungle, this is very important in order to concrete one of ecotourism notion as education center and develop visitor's sense of belonging toward natural and its inhabitant.

Furthermore, these guider also taught to be such a nice person, not only as educator and tour guide they expectable to be such a good friend to visitor therefore there is mutual linkage occur between visitor, nature, and local people such as since visitor perceived exciting experience they willing to promote Citalahab village and TNGHS area as interesting ecotourism destination to their relatives, meanwhile after conducting ecotourism activities visitor expected to be more aware and concern toward natural environment and biodiversity.

Meanwhile in term of benefit sharing, all income from guest house must be deposited to KSM account and at the end of period this profit will be distribute equally to all members, yet regarding from interview with several members, for other ecotourism activities such as home stay, tour guiding, and 
tracking to jungle which is personally conduct, member who are in turn should deposited at last 10\% from profit they acquired from visitor to KSM Warga Saluyu account, this is become agreement to all member for the sake of group welfare. Since this individual ecotourism activities being arranged by shifting method, active member have priority to obtain first shift and then continued by others.

Nonetheless, due to lack number of guest this shitting system is not fully effective to distribute profit to all members, some members-mostly inactive member-perceive this rotation system is inequitable enough because not all member are obtain opportunity to conduct this activities and receive additional income from ecotourism. Therefore to overcome this issue profit sharing is the answer to provide equal distribution income to all members. Regarding to determination of place to visit, before they decide what are the activities will be conduct usually there is an agreement between local guide and visitor or tour operator (if the guest are coming from tour operator) to settle on which place to visit and what time they should be back to village.

In term of financial management, each financial transaction were noted in Buku Kas Harian (daily cash book) and deposited into KSM account where treasurer responsible for this matter. Financial management of KSM Warga Saluyu could be consider as simple accountancy method, they just deduct from several cost such as operating cost to conduct particular ecotourism activities, honor of guide, and honor of porter toward revenue from guest (billing from guest) to obtain profit margin and then this profit margin allocated into KSM account that used for guest house maintenance, member profit sharing, promotion, and other group importance alocation.

Regarding controlling process within ecotourism activities, there is a guide line that arranged the process so that the implementation of ecotourism will still remain with its basic notion. Since local community tends to be the main actor who directly involve in this program, controlling is more often conduct by other parties such as local administration (Balai TNGHS) that assure natural conservation and NGO such as YEH that assure local communities empowerment. 
Staffs from Balai TNGHS regularly perform supervision and controls toward area which become ecotourism destination from deterioration while also maintain cleanliness of an area from any litter. They also observe whether any violation such as illegal logging and other infringe action occur within area of TNGHS, on the other hand local community also support controlling activities by helping Balai TNGHS to protect their surrounding area from any intruder that has cruel intention toward nature and biodiversity of TNGHS in the mean time as well controlling any visitor who may enter TNGHS .

One of the purposes of ecotourism development in TNGHS area is to increase local economic welfare from tourism activity in extent to minimize local community's dependency toward natural environment, therefore to answer this issue the research take place within Citalahab village due to its active existence in term of ecotourism development comparing other village within TNGHS area. Citalahab village comprise of 16 families where those families could be consider as respondent that should be surveyed. Those families representing of 63 indigenous who was born in Citalahab village, yet some of these people where particularly male were go abroad beyond the village in order to obtain better livelihood (merantau) to some major cities such as Jakarta, Bogor, Depok, Tangerang, and Sukabumi and usually return to the village during Lebaran.

Respondent that was surveyed comprise of 30 peoples from 15 different families where these are the whole number of families within village. Those respondent, which visualized in table 9 and 10 has significant role within their families, these respondents comprise of 10 female respondents and 20 male respondents with age between 18-45 years old.

Respondents have various type of occupation.7 person (23.33\%) working as tea plantation labor, 10 persons (33.33\%) tend to be household wife, 5 persons (16.67\%) consider as farmer, and 8 persons (26.67\%) working within ecotourism sector. Those 8 respondents who work in ecotourism sector were the person who devoted their self for the sake of ecotourism development within TNGHS area especially within Citalahab village, some of these people 
working as local tour guide, porter, guest house administrator, and Cikaniki research station honorary worker.

In term of educational level all respondents (100\%) only completing their education at primary school level (Sekolah Dasar), regarding interview with them this low educational level occur because to continue into higher level (junior high school) they have to walk and cross the jungle for almost $20 \mathrm{~km}$ on the way to Kabandungan subdistrict, the nearest junior high school. However, since last few years there was open junior high school (Sekolah Menengah Pertama Terbuka) build within Nirmala village to accommodate this condition therefore children who was born 1995 above were luckier and could reach higher education comparing their parents.

Based on interview from first to third questions, all indigenous people have been lived since they were born and consider as third generation of family's lineage, most of them have ever heard the term of ecotourism from YEH and others terminology from Balai TNGHS and JICA, however something interesting that almost all local people often heard this term apparently they do not understand the meaning terminology of ecosystem itself, refer to interview with these peoples they just understand ecotourism as something could convey goodness for them. However based on interview, respondents agree enough with implementation of ecotourism in their area and the rest tend to be passive, however from all respondents who devote their self for ecotourism development able to explain comprehensively concerning with the elements and infrastructures are needed to support ecotourism implementation. They mentioned physical infrastructure, accessibility, accommodation facilities, electricity, telecommunication, jungle and its ecosystem, as well as local community as crucial elements that need to be concern to achieve ecotourism development program. All respondents were agreeing regarding ecotourism implementation could improve their economic welfare. Yet from the last question, all people also agree if it said ecotourism could bring negative impact toward their life either in term of social or ecological imbalance. Something to emphasize is from this questionnaire all respondents were believed ecotourism as something that could improve their economic welfare. 
The result of validity and reliability testing with Cronbach alpha method, questionnaire consider as valid when "cronbach's alpha if item deleted" result higher than 0.6, it means that question raised are valid to be asking, however reliability testing by using "corrected item correlation" compare to R table $(\mathrm{N}=30)$ stated there are two questions (question no 22 and 30) have lower result than $R$ table $(R$ table $=0.361)$ which means that those questions consider as not reliable, it means the answer from two questions raised does not have relationship and cannot be trusted in term of this research and should be ignore.

Pearson product-moment correlation will determine the relationship between an individual's height and their performance in a long jump (distance jumped) and measure the strength and direction of association, the value of correlation start from -1 (strong wrong correlation value) until 1 (strong and perfect correlation value) which can be mentioned as $-1.00<0<1.00$.

It is clearly describes that correlation occur between ecotourism, community involvement, and natural conservation consider as moderate and positive $(r=0.743$ and $r=0.566)$, which mean that if ecotourism activities increased, the value of community involvement will be increased as well as natural conservation.

The result explain all coefficient correlation have positive strong value and higher than $r$ table. This situation indicates there is significant correlations occur between ecotourism, community involvement, and natural conservation within TNGHS area identified ecotourism has positive impact toward community and natural conservation. This is enlighten ecotourism could be consider as form of solution for community involvement as well as natural conservation and bio diversity protection. There is significant relation between ecotourism, community and natural conservation.

Determinant Coefficient $\left(\mathrm{R}^{2}\right)$ enlighten how much prediction of future outcomes on the basis of other related information, it provides a measure of how well future outcomes are likely to be predicted by the model. In this case $\mathrm{R}^{2}$ for community involvement $=0.743^{2}=0.55$ it means determinant coefficient is $55 \%$, this is mean $55 \%$ community involves within ecotourism activities, and 
the rest are have different activities for example agriculture. In the other hand, Determinant Coefficient for natural conservation $=0.566^{2}=0.32$, it indicates ecotourism only provide $32 \%$ of natural conservation, while the most conservation factors are from others for example biodiversity research projects.

Conservation of biological resources and its ecosystem are of sustainable development form. One of ecotourism principle is to provide particular tourism activities that support protection toward nature and its biodiversity while also obtain benefit for local community's welfare, based on questionnaire distributed and statistical analysis resulting ecotourism should able to deliver this notion into grounded and provide sustainable partnership among nature as tourism object and human as the subject. In term of natural conservation and biodiversity protection ecotourism give significant contribution by offering such activities that directly in compliance with this notion.

Since ecotourism offering nature-based activities, the main aspect that need to be pointed out is these attractions and activities should consist natural elements for instance beauties, authenticities, wildness, uniqueness, and scarcity where it should be able to convey senses of nature-loving and senses of nature-belonging through visitors. Several nature based attraction which in compliance with natural conservation and biodiversity protection are: Tracking inside the jungle: Cikaniki - Citalahab loop trail, Citalahab - Nirmala loop trail, Citalahab - Curug Piit trail, Tea-walk, Canopy-walk, Visiting waterfalls, Bird watching, Night watching, Monitoring endanger species, Visiting traditionalhistorical site, Camping and Hiking

\section{CONCLUSION}

In term of reaction from local community toward ecotourism, local communities particularly within Citalahab village are fully supporting ecotourism implementation at their area, although today these people perceive ecotourism as their side job. There are various aspects appears as factor that supporting as well as constraint ecotourism development within TNGHS area.

While aspects that tend to constraint ecotourism development merely came from internal and external factors. The internal ones that tend to tear down the nature is local traditional activities such as Huma (moving pattern of 
cultivation), and Bedol desa (carry over the village into new place by opening some space of forest). Moreover, till present there is an ongoing issue regarding ecotourism implementation's "pie sharing". However, this issue immediately can be overcome by conducting clannish discussion and meeting between local people and local administrator to determine what the core problems are and how to overcome it. Furthermore, external factors such as illegal logging, unauthorized gold mining, and animal hunting also appear as threat regarding natural conservation and biodiversity protection as well as ecotourism development within TNGHS area

So far based on interview, local people perceived there are no detriment occurs to them as consequences from ecotourism implementation. Indeed, they feel grateful because since ecotourism applied in their area, these local people able to obtain additional income as well as experiencing new horizon being interact with others (visitors). Meanwhile, negative impact that occur toward nature and its biodiversity is not significantly affecting, due to ecotourism notion that standing in the pattern of natural conservation this turn out to be basic principle within implementation phase. However, because of human presence within this area, based on direct observation there are some rubbish seen in some part of the park.

In term of local community involvement, these local people perceive they were urging to be directly involved in this program. Local people were trained to be more professional in tourism sector with particular training and also able to convey basic notion of ecotourism toward visitors. They also being involved within planning, implementation, and controlling phase, furthermore, based on questionnaire distribution and statistical analysis using SPSS 15.0 it stated there are positive significant correlation between ecotourism and community involvement (community involvement $r=0.743$ and natural conservation $r=0.566$ ), which mean that if ecotourism activities increased, the value of community involvement will be increased as well as natural conservation. It means that local community truly and eager to be involved (Determinant Coefficient 55\%) within ecotourism development at TNGHS area. Finally, from this ecotourism development program local peoples were agreed 
that they able obtain economic benefit from ecotourism activities such as from home stay, tour guiding, and porter.

Regarding to determine how correlation between ecotourism and natural conservation appear, interview result and questionnaire distribution provide similar result where those method explained there are positive significant correlation between ecotourism and natural conservation. It means that ecotourism bring positive impact (Determinant Coefficient 32\%) toward natural conservation and biodiversity protection, it shown in several ecotourism activities that representing education toward natural protection.

\section{REFFERENCES}

Cohen, J. M. 1997. Rural Development Participation: Concepts and Measures for Project Design, Implementation and Evaluation. New York: Cornell University.

Cook, R. A., et.al. 2006. Tourism The Business of Travel. New Jersey: Pearson Education.

Dwiyanto, D. 2002. Metode Kualitatif: Penerapannya Dalam Penelitian. Yogyakarta: FIB Universitas Gajah Mada.

Hartono, T, et.al. 2007. Taman Nasional Gunung Halimun-Salak "Menyingkap Kabut Gunung Halimun-Salak. Bogor: Gunung Halimun-Salak National Park Management Project.

Nugraheni, E. 2002. Sistem Pengelolaan Ekowisata Berbasis Masyarakat Di Taman Nasional (Studi Kasus Taman Nasional Gunung Halimun Salak). Bogor: Institut Pertanian Bogor.

Richards, G \& Hall, D. 2000. Tourism and Sustainability Community Development. London: Routledge.

Ross, G. F, et.al. 1996. Tourism Community Relationship. North Queensland: Elsevier Science.

Sharply, R. 2000. Tourism and Sustainable Development: exploring the theoretical divide. Journal of Sustainable Tourism Vol. 8 No. 1, 1-19.

Sugiyono. 2010. Statistika Untuk Penelitian. Bandung: Alfabeta.

Supranto, J. 1997. Metode Riset Aplikasinya Dalam Pemasaran. Jakarta: Rineka Cipta. 
Supriyanto, B \& Ekariyono, W. 2007. 5 Strategi Rekonstruksi dan Sosial Konservasi Di Taman Nasional Gunung Halimun Salak. Sukabumi: Balai Taman Nasional Gunung Halimun-Salak.

Wardiyanta. 2006. Metode Penelitian Pariwisata. Yogyakarta: ANDI. 